This article was downloaded by: [George Mason University]

On: 04 January 2015, At: 10:23

Publisher: Routledge

Informa Ltd Registered in England and Wales Registered Number: 1072954

Registered office: Mortimer House, 37-41 Mortimer Street, London W1T 3J H, UK



\title{
International Peacekeeping
}

Publication details, including instructions for authors and subscription information:

http:/ / www. tandfonline.com/loi/ finp20

\section{Peacebuilding in Timor-Leste: Finding a Way between External Intervention and Local Dynamics}

Maria Raquel Freire \& Paula Duarte Lopes Published online: 19 J un 2013.

To cite this article: Maria Raquel Freire \& Paula Duarte Lopes (2013) Peacebuilding in Timor-Leste: Finding a Way between External Intervention and Local Dynamics, International Peacekeeping, 20:2, 204-218, DOI: 10.1080/ 13533312.2013.791577

To link to this article: http:// dx. doi.org/ 10.1080/ 13533312.2013.791577

\section{PLEASE SCROLL DOWN FOR ARTICLE}

Taylor \& Francis makes every effort to ensure the accuracy of all the information (the "Content") contained in the publications on our platform. However, Taylor \& Francis, our agents, and our licensors make no representations or warranties whatsoever as to the accuracy, completeness, or suitability for any purpose of the Content. Any opinions and views expressed in this publication are the opinions and views of the authors, and are not the views of or endorsed by Taylor $\&$ Francis. The accuracy of the Content should not be relied upon and should be independently verified with primary sources of information. Taylor and Francis shall not be liable for any losses, actions, claims, proceedings, demands, costs, expenses, damages, and other liabilities whatsoever or howsoever caused arising directly or indirectly in connection with, in relation to or arising out of the use of the Content.

This article may be used for research, teaching, and private study purposes. Any substantial or systematic reproduction, redistribution, reselling, loan, sublicensing, systematic supply, or distribution in any form to anyone is expressly 
forbidden. Terms \& Conditions of access and use can be found at http:// www.tandfonline.com/page/terms-and-conditions 


\title{
Peacebuilding in Timor-Leste: Finding a Way between External Intervention and Local Dynamics
}

\author{
MARIA RAQUEL FREIRE and PAULA DUARTE LOPES
}

\begin{abstract}
This article highlights the importance of interaction between peace missions and local dynamics, drawing on Tsing's work on frictions. It is centred on the United Nations (UN) peace intervention in Timor-Leste, discussing different examples of frictions, which have the potential to undermine or empower the peacebuilding efforts underway. The analysis stresses the unpredictable effects of applying the UN liberal peace model. It is argued that processes of friction, often consisting of an incremental build-up of intermediate results shape and form the (un)sustainability of any peacebuilding process initiated by an external intervention and, consequently, should be identified and analysed in order to enhance or minimize their positive/negative contribution towards building peace.
\end{abstract}

\section{Introduction}

This paper adopts a critical approach to the United Nations' (UN) liberal interventionist peacebuilding model, assumed as universal and reflected in the mandates of its differentiated missions in the field. The multidimensional nature of peacekeeping missions has resulted in their increased responsibility for peacebuilding objectives, for example, through the inclusion of institution-building and economic reform aims in their mandates, as is visible in the case of Timor-Leste. The analysis focuses on how the interaction between the UN model of intervention and local dynamics takes place, following the analytical model of Anna Lowenhaupt Tsing (2005) and her concept of frictions. Using Tsing's concept of friction permits a focus on the unpredictable effects that result from the implementation of the UN model in its encounter with local cultural and power dynamics. It is argued that the processes of friction constitute crucial elements of the (un)sustainability of a peacebuilding process. Frictions should therefore be identified and analysed in order to enhance or minimize their empowering or undermining contribution towards building peace. The article argues that the nature of friction, and of the results it prompts, determines the potential (or not) for peacebuilding efforts to be fully embedded in sustainable local context dynamics.

The case study of Timor-Leste gains relevance in this discussion because of the depth and breadth of the UN intervention. It took the shape of a transitory administration governing the country in the first years, and subsequently assisted the newly independent state and democratically elected government in their efforts to consolidate governance capabilities towards the aim of peacebuilding. This intervention encompassed several peace missions with mandates adapted sequentially to local 
changes. There is evidence that some of the mandates were defined with the input of local governing elites, but the violent outbursts of 2006 may best be explained by those voices that were never heard by the UN. Consequently, analysing different examples of friction derived from the interaction between the UN model and local dynamics, as well as their results, becomes crucial to better understand the (un)sustainability of peacebuilding practices in Timor-Leste.

Building on Tsing's work on frictions, the article starts by describing the framework wherein frictions are understood as processes which continuously generate readjustments by the actors on the ground. It then proceeds to briefly frame UN policies and practices of intervention in the context of peacebuilding, highlighting the main dynamics associated with the UN liberal peace model and how this was reflected in the missions deployed in Timor-Leste. The focus will be on the frictions derived from the interaction between the United Nations Integrated Mission in Timor-Leste (UNMIT), ${ }^{1}$ as the main external actor, and the Timorese government and other relevant agents. This contextualization paves the ground for an analysis of the interaction between external and internal actors regarding public security and democracy, here focused on election practices. The article concludes by demonstrating that these dynamics are not straightforward or linear. On the contrary, they vary in intensity, they may be intertwined, and they change according to the political, economic and social contexts in which they are embedded. Thus, analysing frictions resulting from the interaction between the external and the local is central to designing a sustainable peacebuilding process, and allows these to be understood as embedded in local dynamics of legitimacy and authority, and building on local ethno-practices related to culture and language. Therefore, and in line with Tsing's argument, studying frictions when analysing peace missions reminds us of the importance of interaction in defining the (un)sustainable path of a peacebuilding process.

The article draws extensively on fieldwork conducted in June-July 2012 in Timor-Leste, which included primarily semi-structured qualitative interviews focusing on the relation between the United Nations' missions and the national political, economic and social dynamics. The interviewees included Timorese key political leaders and opinion-makers, foreign advisors, United Nations personnel as well as staff from other multilateral and bilateral aid agencies. The authors gave particular attention to interviewees who had multi-mission experience to allow for a comparison on their own terms, which provided insightful information. Information was also gathered from accounts provided by different actors as the work proceeded. Finally, observation of the 2012 parliamentary elections, where the authors were official accredited external observers, provided another source of information. This took place in the District of Dili, in two subdistricts: Cristo-Rei and Vera Cruz, and in each sub-district both urban and rural voting centres were visited.

\section{Frictions as Processes of Incremental Results}

This paper draws on the concept of friction as developed by Tsing, according to which frictions are 'the awkward, unequal, unstable, and creative qualities of 
interconnection across difference', ${ }^{2}$ that allows for 'creative re-imaginations as an organic response to "awkward engagements". ${ }^{3}$ The interrelation Tsing suggests between the external and the local reveals the difficulties in engaging pre-defined models, such as in this case of the UN model of intervention, taken as universal, with the specificities of local realities. For instance, in Timor-Leste universal schemes were applied directly without immediate local readjustment. Starting from an ethnographic basis, Tsing argues that differentiated results from the universal model in distinct places are explained by their ethno-specific characteristics. Therefore, understanding the quality of this ethnographic journey from the external to the local makes a difference in unpacking the differentiated responses to the universal approaches that are put in place. ${ }^{4}$ In this setting, she draws attention to the need to look at innovative ways of engagement in these external-local connections; the point of intersection where frictions are revealed. Tsings' argument rests on the fact that friction should be seen in this encounter not as 'as an emergent property'. ${ }^{5}$ Additionally, Tsing adds that in this journey, 'friction reminds us that heterogeneous and unequal encounters can lead to new arrangements of culture and power'. ${ }^{6}$ Therefore, her main argument is that in the encounter between the universal and the local, differentiated results will emerge, essentially due to specific ethnographic aspects that make actionreaction-responses distinct from place to place. In fact:

Speaking of friction is a reminder of the importance of interaction in defining movement, cultural form, and agency. Friction is not just about slowing things down. Friction is required to keep global power in motion. It shows us... where the rubber meets the road. Roads are a good image for conceptualizing how friction works: Roads create pathways that make motion easier and more efficient, but in doing so they limit where we go. The ease of travel they facilitate is also a structure of confinement. Friction inflects historical trajectories, enabling, excluding, and particularizing. ${ }^{7}$

The framework of analysis presented by Tsing is most useful in drawing attention to the frictions that emerge from the encounter of the universal - in this case the liberal peace model - with the local cultural and power dynamics. Frictions might be understood as a process from which differentiated results emerge. This means that in this external-local encounter it is possible to find casuistic moments as well as processes in motion that might contribute to the consolidation of a certain practice, or instead obstruct it. Looking at encounters in this way assists in better explaining the differentiated results of peace missions and frictions' potential in bringing (in)stability to the peace processes being developed, here in the particular context of Timor-Leste.

Intervention models are not implemented in an empty context without rules of conduct or without people that carry a history and have their own dreams. Consequently, any type of external intervention produces friction as a result of the interaction between external and local actors, and their objectives, experiences and expectations. ${ }^{8}$ These frictions vary with context and over time, as well as forming on-going processes of engagement which may contribute to the efforts and goals of an intervention or, on the contrary, undermine them. Consequently, 
frictions may constitute episodes of incremental experiences, the results of unplanned engagements, which may or may not trigger changes or adjustments to the intervention policies and/or instruments. They constitute on-going processes that support and/or undermine, in different moments, efforts developed by both external and local actors towards building sustainable peace. These frictions may be visible and evident, leading to policies and initiatives to either address them preventively or include them constructively. On other occasions they may be invisible - or at least invisible to all, or some, relevant actors - and consequently, some unexpected and seemingly unrelated event or dynamic can easily disrupt stability and peace. Tsing's framework is applied to the case of Timor-Leste through an analysis of public security and democracy which shows how, in these two main areas, frictions as processes are evidenced, suggesting a potential for frictions to lead towards the (un)sustainability of the UN peacebuilding process being developed.

\section{United Nations: Building the Peace}

The UN approach to peace missions has evolved both conceptually and in practice, with comprehensive multidimensional peace missions including long-term objectives geared towards building sustainable peace. Its liberal content, framed within the UN neoliberal model, became crystallized in the so-called 'peacebuilding consensus'. This assumes the universal validity of liberal peace premises and the consequent creation of an objective peace that can be reproduced internationally through reforms in conflict settings. In this way, international interventionism has promoted 'peace as governance' meaning the implementation of reforms at local level, but where governance 'becomes a key tool and a key objective' of the liberal peace model, resulting in an externally led and designed peace. ${ }^{9}$ This has the potential to produce a detachment of the locals from the process and contents, implying resistance and eventually leading to unsuccessful results. The case of Timor-Leste illustrates well these dynamics, for the extent of involvement of the UN, the different stages and changing modes of this involvement, and because some see it as an example of successful intervention. ${ }^{10}$

Timor-Leste has been the stage for diverse UN missions, from assistance to the popular consultation regarding its future status as an independent state, back in 1999 , to the use of force in the face of violence, to the definition of an integrated multidimensional mission in the post-violence setting of 2006. The United Nations Transitional Administration in East Timor (UNTAET) mission, deployed in February 2000,${ }^{11}$ was tasked with building the country and preparing it for independence, scheduled for May 2002. UNTAET became, thus, responsible for the administration of Timor-Leste, with executive, legislative and judicial powers, until its independence. The focus on building a democratic state reflected the top-down (outside-in) nature of the UN model of intervention. The depth and extent of this mission not only created the foundations of the Timorese state, but it also structurally influenced all subsequent missions as well as the template used by the Timorese government for consolidating the 
state to this day. ${ }^{12}$ After independence, the UN downgraded its involvement in Timor-Leste to a political office, which was ultimately revealed to be a premature development given the fragile institutional, political, economic and social context. The emergence of violence led to a more robust intervention and finally in August 2006, the United Nations Integrated Mission in Timor-Leste (UNMIT) was established, ${ }^{13}$ aiming at the development and capacitation of institutions, building on progress made at the level of governance, continuing the process of transfer of responsibilities to the Timorese, and focusing on economic and social development. Since the beginning, the intervention in Timor-Leste demonstrated a preventive concern, but this was not only inadequate to reality, but also reflected a significant temporal hiatus between decision-making and implementation. With UNMIT the approach did not change:

... the international community returned in greater numbers, but with essentially the same model that, apparently, had not served it so well in the years before, namely large public sector development programmes and a heavy emphasis on imparting 'capacity' through technical assistance. Moreover, the basic human mode of delivery was also the same: individuals drafted in from foreign fields and working in a context politically, culturally and linguistically alien to them. A policy is only as good as the disposition and skills of the persons charged with implementing it. ${ }^{14}$

Nevertheless, the 2007 parliamentary and presidential elections took place without any major incidents, despite the politically volatile situation associated with growing tensions within the security institutions, which eventually set the context for the attempted murders of President Ramos-Horta and Prime-Minister Xanana Gusmão on February 2008. ${ }^{15}$ The swift normalization after the instability that these events generated, showed that the underlying situation was more stable and predictable, allowing 'UNMIT [to continue] its "one United Nations system" approach, consistent with its integrated strategic framework'. ${ }^{16}$ The 2012 presidential and parliamentary elections led to the extension of UNMIT's mandate until December 2012 and were described as free and fair by national and international observers. UNMIT activities are described as revealing significant progress in the transition process, especially concerning public security, and alternative scenarios for the future presence of the UN in Timor-Leste are under discussion, reflecting the UN's commitment to continue involvement in the Timorese peacebuilding process. ${ }^{17}$

In June 2012, Timor-Leste celebrated the tenth anniversary of the restoration of its independence. After one decade, and with a UN mission still present in the country, Timorese political and security institutions are functioning, civil society is slowly organizing, and the economic situation has improved with incoming resources from the Oil Fund. However, structural problems remain at all of these levels. The process of 'Timorization' - the local level assuming responsibility for decision shaping, making and implementation - has been taking place, with the transference of competencies from the UN mission to the central authorities, with a clear downsizing of UNMIT. According to the Acting Special Representative of the United Nations Secretary-General (UNSRSG) to Timor- 
Leste, Mr. Finn Reske-Nielsen, ${ }^{18}$ Timor-Leste is stable and in the course of development, allowing the decision to withdraw UNMIT by the end of 2012 and leave a political delegation in the country, mainly with a monitoring mandate. The political authorities and influential persons in Dili agree that it is time for UNMIT to leave, ${ }^{19}$ not least because it would symbolize international recognition that the country may follow its own path.

Still, as Lothe and Peake argue, '[in] Timor-Leste, as elsewhere, stabilisation has proven unable to contend with the "underlying" causes or drivers of conflict, including persistent political cleavages, ethnic and community divisions, and social and economic inequalities'. ${ }^{20}$ The holding of free and fair elections, though constituting a positive signal, is not sufficient to assure a democratic path. ${ }^{21}$ The new government after the parliamentary elections of 2012 faces the task of controlling corruption and putting in place an inclusive reform programme. Capacity-building both in human and material terms has been referred to as the main challenge for an independently run Timor-Leste. This is acknowledged by the local authorities and is visible in the preparations for UNMIT's successor after its withdrawal, as well as initiatives to further bilateral cooperation. ${ }^{22}$ The central problem, however, remains local limited learning experience and their insufficient acquisition of analytical decision-making and policy implementation skills. This issue refers directly to what has been called one of the main faults of the UN presence in Timor-Leste, its inability to capacitate. In the words of Lemay-Hebert, 'local actors have to be recognized as true partners in the statebuilding process rather than mere recipients of foreign aid'. ${ }^{23}$

The liberal agenda has unreflexively promoted Western values as superior to non-liberal local and customary procedures, ${ }^{24}$ thus not taking into account the coexistence between the formal and the informal as a reality in Timor-Leste, where official and traditional are part of daily life. Local understandings about UNMIT in the current context point to the fact that it has fulfilled its mandate, that it is time to withdraw as it is now hampering the affirmation of the country's full sovereignty by maintaining a strong administrative-advising dependency structure and a strong foothold in Timor's everyday politics due to its mandate. Dealing with the parallel functioning of formal and informal systems remains a central feature of Timorese society, at all levels, an issue with which the UN has always had difficulty dealing. For a better understanding of the evolving course of Timor-Leste, the analysis of frictions is central, because it allows us to investigate both opportunities and challenges in external-local interactions.

\section{Frictions in Public Security and Democracy}

In the case of Timor-Leste, we identified frictions as processes in two different areas: public security and democracy. These areas have been considered crucial to the UN's efforts to promote peacebuilding in Timor-Leste and have also constituted priority issues for the Timorese governments. Both public security and democracy demonstrate how the interface between the external and the local is complex and dynamic, and not a hierarchical structure where the local will simply adjust to the external and, therefore, not making 
'everything everywhere the same'. Furthermore, mapping the (dis)embedding nature of these frictions towards the peacebuilding process becomes crucial to promote its sustainability.

\section{Public Security}

The dimension of public security in Timor-Leste constitutes a good example to illustrate how frictions in this case, potentially contribute to consolidating stability at different levels. At the level of interaction between national governmental officials and the United Nations mission, after 2006, one can observe a high level of planned and implemented collaboration. On 1 December 2006, the Acting UNSRSG, Finn Reske-Nielsen, and the Timorese Prime-Minister, José RamosHorta, signed an Arrangement, ${ }^{25}$ which included a Phased Approach to UNMIT's support to the PNTL (Policia Nacional de Timor-Leste). ${ }^{26}$ The implementation of this Phased Approach - initial, consolidation and full reconstitution phases - aimed at the creation of a Timorese autonomous and independent, as well as operational and effective, police structure.

During the 'initial phase' (2006-2009), local police officers were structurally subsumed under UN police (UNPOL) command, with the UN Police Commissioner acting as the 'interim PNTL General Commander'. ${ }^{27}$ From May 2009 to March 2011, the 'consolidation phase' was implemented with the gradual handover of responsibilities to PNTL, which became the primary actor responsible for the conduct of police operations. ${ }^{28}$ This transfer was not time bound, but rather based on benchmarks achieved and on performance targets attained, set out for this purpose in the PNTL reform, restructuring and rebuilding plan. ${ }^{29}$ Additionally, this collaboration was further developed in the field, by having UNPOL officers serving alongside PNTL police officers in order to 'advise, support and assist them in conducting police operations' ${ }^{30}$ These joint teams in the field allowed for UNPOL to conduct on-the-job-training. ${ }^{31}$

In the different interviews with both UN and Timorese governmental officials, it became clear that the approach to training had been significantly reformed over the course this arrangement between UNMIT and PNTL. ${ }^{32}$ It is regularly pointed out that UNMIT has been the most multi-national mission with a record number of contributing countries. ${ }^{33}$ However, this seemingly positive contribution was also identified as a source of concern by the Timorese government. The pool of UN members from which UN police officers came, included states with a questionable track record on democratic practices and human rights protection in their own countries. ${ }^{34}$ In addition, the different UN police officers emphasized different values, modes of conduct and procedural aspects when training Timorese police forces, according to their various national experiences. This resulted in an awkward and unexpected outcome which could have derailed the collaboration between governmental and UN actors and undermined the consolidation of the Timorese national police. However, the Timorese government identified this friction early on and decided to become fully responsible for the recruitment and training of PNTL forces, resorting to bilateral agreements with a few strategic donor countries to guarantee the creation and consolidation of a well-trained 
police force, focused on upholding the Timorese Constitution and protecting human rights. ${ }^{35}$

By March 2011, UNMIT handed over 'to PNTL the responsibility for the conduct and command and control of all police operations in Timor-Leste' initiating the 'full reconstitution phase'. ${ }^{36}$ According to UNMIT Police Commissioner, Luís Carrilho, the first phase required that UNPOL 'maintained security, public order and controlled crime'; then UNPOL focused on capacitybuilding and on-the-job-training of PNTL officers; and currently '[they] meet at the big events', ${ }^{37}$ such as elections. The current PNTL General Commander, Longuinhos Monteiro, concurred that 2012 will end with a 'self-sustainable' PNTL, and claimed that the departure of UNMIT 'will not have much impact on the operational activities' of PNTL. ${ }^{38}$ This example provides a good illustration of how a friction addressed in a timely fashion, contributed to support the international (UN) and local (government) efforts towards creating a Timorese autonomous police force.

At the local-local level, where people's daily lives take place apart from the Western understandings of the local, ${ }^{39}$ frictions become daily processes which have the potential to erode stability in the everyday interaction between police officers and the population. At this level, traditional authority leaders (liurais) still manage conflicts in their communities (sucos),${ }^{40}$ focusing on retribution and the restoration of social order and harmony, and frictions have the potential to occur. However, from our observation, at this level of interaction the frictions are a process of constant interaction between the modern recently established police structure and normative framework, and the traditional values and ways of addressing conflicts. In one such case, during the 'reconstitution phase', where PNTL is responsible for maintaining security, public order and controlling crime, we were told that the police were called to a certain community due to a murder. On arrival, the whole community was waiting for them and a row of empty chairs was in place. The UN police officer remained behind, observing, and the PNTL officer was received by the local liurai, who asked him to sit in one of the chairs. They talked for a while among themselves and with others also seated, with the remaining people of that small community surrounding them. The PNTL officer returned to the car and informed the UN police officer that the issue had already been resolved: another person had also died and the liurai, the families of those involved and the community considered that justice had been obtained. No police report on the incident was filed. Consequently, there is no official record of this or any other similar occurrences.

This awkward engagement between the legal security structures and the traditional authority framework was, in our understanding, part of a friction. It is a process that allows for continuity, which, in this case, meant a constant adjustment between two different authoritative frameworks that still coexist, without fully opposing each other. This account shows how traditional authorities recognize the legitimacy of the PNTL, calling them and involving them in their problem solving approach; and, in turn, the PNTL officer also recognized the legitimacy and authority of the liurai. There is a clear, even if unconscious, opportunity for both frameworks of action to work together towards social stability, 
consolidating the PNTL's authority and legitimacy while not dismissing traditional authorities. This process is understandably unplanned and awkward, particularly for the PNTL. The process is also extremely dependent on the actual police officer on duty and his/her relation with the community and Timorese traditional authorities. However, these frictions, where mutual recognition take place and co-supporting dynamics exist, suggest the possibility of synergies towards sustainable peace.

\section{Democracy}

Elections constitute another good example where frictions take place, holding the potential to both support and undermine the democratization process underway in the country. The 2002 Timorese Constitution states that sovereign and local government members are to be elected, 'through universal, free, direct, secret, personal and regular suffrage'. ${ }^{41}$ In general, the implementation of the electoral process in the parliamentary elections of 7 July 2012 complied with UN standards for free, fair and competitive elections. The campaign period developed without major incidents and within the Timorese legal framework in effect ${ }^{42}$ and the actual elections 'took place in a calm atmosphere and were organised in a broadly transparent and credible manner'. ${ }^{43}$ The electoral process 'was peaceful and orderly, with no significant security incidents or irregularities', 44 'and generally met international standards'. ${ }^{45}$

Friction as an unplanned process is most visible in this case in the procedures for counting votes. Transparency and public participation are the main elements that reflect the Timorese appropriation of the UN electoral model. All the procedures are conducted with public scrutiny, including vote counting. ${ }^{46}$ Besides accredited national and international observers and the population at large, a group of officially accredited representatives from political parties and political coalitions running for election oversees the whole process at each polling centre, including the validation of each vote. ${ }^{47}$ The president of each polling centre reads out loud each vote and shows the voting ballot to all present, separating the valid votes by candidates, and from null and blank votes. ${ }^{48}$ Whenever a question is raised regarding a vote's validity, the group of official accredited representatives discusses if it accepts (aceita) or if it appeals (reclama) the polling officials' proposal. Any doubt or appeal is decided by a majority of at least six polling officials, with the president of the polling centre casting a vote in case of a tie. ${ }^{49}$ The polling officials attempt to reach a consensus on the validation of the vote in question by listening to the different official representatives' suggestions and arguments and by mediating any opposing positions. Once, and if, consensus is reached ${ }^{50}$ it becomes a communitarian decision that acquires legitimacy and is adopted by all. These decisions, however, are not registered in any official document or reported to any official authority.

Consequently, different polling stations may decide contrarily on similar cases, depending on the discussions and conclusions of the particular group of monitoring and electoral officials at each polling station. In fact, what is really fundamental is that there is agreement on a decision to be made, which is 
considered legitimate and final. This illustrates how an unplanned and sometimes awkward encounter results from the local implementation of the UN electoral model. This friction is again, in our understanding, a process that occurs in every election held in Timor-Leste, allowing for the traditional communitarian locus of decision to have an active role in the national electoral process. In this case, we consider that this friction contributes both to the strengthening of the democratic participative process through the enlarged involvement of the local population and their representatives, and to reinforcing the legitimacy of the elected candidates at the community level.

A second example of friction we identified was associated with decisions taken at the polling station regarding irregularities. In one such case, an unregistered voter showed up to vote. Voting procedures establish that $\mathrm{s} /$ he can vote as long as $\mathrm{s} /$ he can provide identification confirming $\mathrm{s} / \mathrm{he}$ is from that suco and her/his name is registered in an additional voters' list. So, s/he was allowed to vote, but when s/he went to get the forefinger inked, the indelible ink controller realized s/he had already voted elsewhere. Voting stopped at that polling station and both polling officials and accredited observers, including the National Electoral Committee (CNE) representatives, discussed what to do. The decision was to continue with the voting and disregard the situation. S/he had after all already cast her/his vote and deciding otherwise would prevent all other votes cast up to that moment from being counted. Later on the same day, a senior CNE official, who was visiting different voting centres to make sure all was running smoothly, arrived and a bystander reported what had happened. The official questioned the CNE's representatives observing the voting procedures at that polling centre and they all stated that no problems or irregularities had been observed so far. This is clearly an unexpected, unplanned and awkward engagement resulting from the application of an external electoral model into a strong community-based society.

Voting multiple times constitutes an irregularity; it is not acceptable; it undermines democracy. However, the commitment towards democracy in Timor-Leste is absolutely anchored in the idea that 'no one should be denied the possibility to vote'. ${ }^{51}$ The possibility of multiple voting is close to null due to the use of the indelible ink. Consequently, the number of such irregularities was considered by those officials and observers to be negligible when compared to the importance of counting every vote and making sure the community knew their votes would be counted. This example illustrates how consolidating the concept and practice of democracy in Timor-Leste may not always fully comply with the requirements of the UN electoral democratic model but also how different frictions may potentially contribute to strengthening or undermining the embeddedness of democracy in Timorese society.

The local governance structures at the suco level are yet another example to illustrate how the results of the interaction between the modern and traditional political structures may have the potential to structurally undermine national stability. In 2004, legislation was passed in order to define the electoral process for the liurais (suco leaders) and the Suco councils, which were so far chosen based on sacred aspects or by inheritance. ${ }^{52}$ If, on the one side, this recognized 
the importance these traditional leaders and authorities had in society, on the other hand it constituted a clear attempt to democratize local government according to modern liberal principles. ${ }^{53}$ For instance, women can now be elected Suco leaders ${ }^{54}$ and Suco councils have to include two women, a young man and a young woman as well as a female or male elder. ${ }^{55}$ Elections were held in 2004/ 2005 and 2009. Results reflected different dynamics. Female Suco leaders were 1.5 per cent and 2.2 per cent, respectively, reflecting some openness, but still a high resistance to women leaders. In some sucos two parallel structures remained; the elected democratic local governance structure and the traditional one. These dynamics constitute a structural source of frictions, which have the potential to create fissures in the community's social tissue.

\section{Conclusion}

The UN presence in Timor-Leste accompanied the process of popular consultation that led to independence and state consolidation in the past ten years. This presence assumed different formats and mandates according to the identified needs, revealing flexibility and capacity of adaptation, but also the challenges involved in responding adequately to extreme situations. This article analysed the relationship between external intervention and local actors; the intersection where frictions take place. The analysis of frictions resulting from these interactions demonstrated how these different dynamics have been taking place in Timor-Leste, revealing a process that is not straightforward or linear. In fact, as argued, they vary in intensity, they may be intertwined and they change according to the political, economic and social contexts in which they are embedded. This means they might be understood as on-going processes of awkward engagements and, constituting crucial elements in the (un)sustainable nature of a peacebuilding process.

The examples of the evolving nature of security forces and the democratizing processes in Timor-Leste are relevant in exemplifying these inter-connections in differentiated forms of friction that have emerged between the UN intervention and the local dimension. In the case of frictions, we provided two examples that illustrated the unplanned and unexpected nature of the incidents, showing how these awkward and potentially destabilizing engagements actually contributed to supporting and embedding 'universals'. In the case of public security, a seemingly positive characteristic of the UN mission, the fact that it was the most multi-national intervention so far resulted in unplanned and unstable results regarding the upholding of Timor-Leste's Constitution. Several of the contributing states to the UN police force provided officers who had no democratic or human rights experience. This reality created awkward engagements between rendering a UN sanctioned model operational in Timor-Leste and the means (personnel and training methodology) to effectively do it. This situation led the Timorese government to take full responsibility for training its police force, resorting to bilateral agreements for specific issue-areas.

This friction triggered a response that prevented a potentially destabilizing dynamic regarding the consolidation of democratic and human rights protective 
practices by the newly created and trained Timorese police. Similarly, the episode regarding double voting in the 2012 parliamentary elections, although clearly against UN democratic procedures and values, ended up creating an opportunity for the community to decide the course of action and, consequently, provided legitimacy to their decision to disregard the incident. Moreover, this decision was based on the principle that every vote should count and that this was more important than the actual irregularity. The legitimacy of community decisions associated with the commitment towards a broader understanding of democracy allowed the reversal of a potentially destabilizing friction into a community-based legitimacy and democratic strength. As Tsing puts it, universals, such as democracy, 'are limited by the practical necessity of mobilizing adherents' and they should be 'considered as practical objects accomplished in a heterogeneous world'. ${ }^{56}$

This also holds true when frictions are understood as on-going processes. These frictions can be found, in the Timorese case, at the level of implementation of the model, where daily interactions between the external model and the local structures take place. For instance, there is a constant friction between the Timorese modern police and the local authorities' approach to restoring stability and peace. This process is unplanned and characterized by awkward engagements between police officers and local leaders, creating a constant friction between these structures. In this case, the process is extremely dependent on the actual actors involved; their perceptions, values, beliefs and even loyalties. This article describes an example which contributed to the restoration of social order and harmony, but where potential for these traditional community-based decisions to create unstable social dynamics also exists. Consequently, these frictions need not necessarily be eliminated, but need to be identified, monitored and nourished when contributing in a constructive manner to peacebuilding, or addressed to prevent or alleviate their potential negative impact on the peacebuilding process underway.

Also, both the vote counting procedures and the election of Suco Leaders (liurais) provided other examples where frictions are taking place with different impacts. In the first case, although running the risk of distinct polling centres deciding to validate votes differently, community-based decisions are introduced into the UN democratic electoral model and, in fact, this friction allows democracy 'to spread as [a] framework for the practice of power'. ${ }^{57}$ Consequently, this process contributes to the local legitimacy of democratic, albeit community based, values in the Timorese electoral model. The second example given, regarding the election of the liurais has the potential to work in the opposite direction. The plan to democratize local government did not exactly conclude as expected. Values and practices do not change nor are they transferred from one system to another by decree. In this case, this on-going friction, this structural process of awkward engagements between the UN democratic governance model and the Timorese traditional authority system, is yet to be fully unravelled. The potential to undermine social stability is enormous, but it very much depends on the framing of this transference and on the confidence-building measures adopted. 
The analysis provided in this article speaks directly to Tsing's work on how 'universals become practically effective', ${ }^{58}$ illustrating how frictions are ongoing processes. For the process of peacebuilding it is crucial to take into account how the external intervention model may become adjustable and embedded in local processes of legitimacy and authority. This allows for a natural combination of external assistance with local specificities, without raising issues about imposition or alienation. Concurring with Tsing, 'the possibilities of friction, ${ }^{59}$ are enormous and the Timorese case illustrates how including the local, not only at the institutional level, but also regarding policy implementation, becomes fundamental in a sustainable peacebuilding process. Analysing frictions alerts us to the potentially disruptive or constructive dynamics that can be found in the interaction both at the national, but probably more importantly, at the everyday local level. The case study of Timor-Leste highlights the importance of identifying potential frictions in order to minimize/promote their impacts in building a sustainable peace in the country. The example of Timor-Leste shows dynamics of both convergence and divergence between the external UN model and the Timorese local social framework of action, with the external and the local both intertwining and conflicting with each other, as analysed, constituting a most interesting case-study in terms of lessons learnt and lessons to be learnt.

\section{ACKNOWLEDGEMENTS}

The authors acknowledge financial support from the Portuguese Foundation for Science and Technology (FCT) for the research work conducted within Project PTDC/CPJ-CPO/115169/2009 (COMPETE-FEDER) on 'Peacebuilding and Sustainable Peace: UN Missions in Timor-Leste and Portugal's Contribution'. The authors acknowledge also support from Fundação Oriente for the conduct of field research in Timor-Leste. The authors would also like to thank the editors of this special issue and the anonymous reviewers for their comments on previous versions of the article, as well as Annika Björkdahl for her most insightful comments on an earlier draft.

\section{NOTES}

1. S/RES 1704 (2006), 25 August, with subsequent extensions S/RES/1802 (2008), 25 February; S/ RES/1867 (2009), 26 February; S/RES/1912 (2010), 26 February; S/RES/1969 (2011), 24 February and S/RES/2037 (2012), 23 February.

2. Anna Lowenhaupt Tsing, Friction: An Ethnography of Global Connection, Princeton, NJ: Princeton University Press, 2005, p.3.

3. Ibid., p.xi.

4. Ibid., p.7.

5. Ibid., p.7.

6. Ibid., p.5.

7. Ibid., p.6.

8. Ibid., p.3.

9. Oliver Richmond, 'Beyond Liberal Peace? Responses to "Backsliding", in Edward Newman, Roland Paris and Oliver Richmond (eds), New Perspectives on Liberal Peacebuilding, Tokyo: United Nations University Press, 2009, p.57.

10. United Nations Peacekeeping, 'Success in peacekeeping' (at: www.un.org/en/peacekeeping/ operations/success.shtml). 
11. UNTAET was officially established in October 1999 (S/RES/1272 (1999)), and a small team led by Sérgio Vieira de Mello arrived the following month. However, the whole mission took some time to be fully operational (February 2000).

12. Tanja Hohe, 'The Clash of Paradigm: International Administration and Local Political Legitimacy in East Timor', Contemporary Southeast Asia, Vol.24, No.3, 2002, pp.569-89; Nicolas Lemay-Hébert, 'Coerced Transitions in Timor-Leste and Kosovo: Managing Competing Objectives of Institution-building and Local Empowerment', Democratization, Vol.19, No.3, pp.46585.

13. S/RES/1704 (2006) (see n.1 above).

14. Elisabeth Lothe and Gordon Peake, 'Addressing Symptoms but not Causes: Stabilisation and Humanitarian Action in Timor-Leste', Disasters, Vol.34, No.3, 2010, pp.427-43, pp.434-5.

15. S/RES/1802 (2008) (see n.1 above).

16. $S / 2011 / 32$.

17. Interview by authors with Finn Reske-Nielsen, Acting UNSRSG to Timor-Leste, Dili, 6 July 2012.

18. João Manuel Rocha, 'Timor-Leste votou para escolher Governo que deve ser uma coligação', Público, 6 July 2012 (at: www.publico.pt/Mundo/timorleste-vota-para-escolher-governo-quedeve-ser-uma-coligacao-1553823).

19. Interviews by authors with João Azevedo, Legal Advisor to the Timorese Parliament, Dili, 28 June 2012; Zacarias da Costa, Minister of Foreign Affairs (2007-2012), 4 July 2012; Fidelis Magalhães, Chief of Staff of the Office of the President, Dili, 28 June 2012; and José RamosHorta, President of the Republic of Timor-Leste (2007 2012), Dili, 1 July 2012.

20. Lothe and Peake (see n.15 above), p.440.

21. On the 2007 elections see the comprehensive analysis by Michael Leach, 'The 2007 Presidential and Parliamentary Elections in Timor-Leste', Australian Journal of Politics and History, Vol.55, No.2, 2009, pp.219-32.

22. Reske-Nielsen (see n.18 above) and Azevedo (see n.19 above).

23. Nicolas Lemay-Hebert, "The "Empty-Shell" Approach: The Setup Process of International Administrations in Timor-Leste and Kosovo, Its Consequences and Lessons', International Studies Perspectives, Vol.12, No.2, 2011, pp.190-211, p.206.

24. Oliver Richmond, 'De-Romanticising the Local, De-Mystifying the International: Hybridity in Timor Leste and the Solomon Islands', The Pacific Review, Vol.24, No.1, 2011, pp.115-36, p.116.

25. Arrangement on the restoration and maintenance of public security in Timor-Leste and on assistance to the reform, restructuring and rebuilding of the Timorese National Police and the Ministry of Interior Supplemental to the Agreement between the United Nations and the Democratic Republic of Timor-Leste on the Status of the United Nations Integrated Mission in TimorLeste, 1 December 2006.

26. Ibid., Chapter III, Section 6.

27. Ibid., Chapter III, Section 5.

28. Ibid., Chapter III, Section 8.

29. Ibid., Chapter III, Section 8.

30. Ibid., Chapter III, Section 8.

31. Interview by authors with Luís Carrilho, UNMIT Police Commissioner (2009-2012), Dili, 3 July 2012.

32. Ibid., and interview by authors with Longuinhos Monteiro, PNTL General Commander (since 2009), Dili, 6 July 2012.

33. Carrilho (see n.31 above).

34. Countries such as Zimbabwe, Nigeria, Singapore or China.

35. Carrilho (see n.31 above) and Longuinhos Monteiro (see n.33 above).

36. Arrangement on the restoration and maintenance of public security in Timor-Leste (see n.25 above), Chapter III, Section 9.

37. Ibid.

38. Longuinhos Monteiro (see n.32 above). The PNTL General Commander did recognize a problem regarding material means to maintain the PNTL everyday operational activities, but he also remarked that this is a concern for the future government.

39. Oliver Richmond, 'Becoming Liberal: The Everyday, Empathy, Post-Liberal Peacebuilding', CPCS Papers, 2008 (at: www.st-andrews.ac.uk/intrel/media/becoming_liberal.pdf).

40. Suco is a community organization formed on the basis of historic, cultural and traditional circumstances, having an area established within the national territory and a defined population. Lei 3/ 2009, 8 July, Article 3, 1. 
41. Constitution of Timor-Leste, 2002, article 65.

42. Ramos-Horta (see n.19 above); Carrilho (see n.31 above); Longuinhos Monteiro (see n.33 above).

43. European Union Election Observation Mission to Timor-Leste 2012, Press Release, Dili, 09/07/ 2012 'Peaceful and Well Organised Parliamentary Elections 2012 a Step to Democratic Consolidation' (at: www.eueom.eu/files/pressreleases/english/EN_PressRelease_PreliminaryStatement_ 20120709.pdf).

44. Australian Foreign Minister Bob Carr Joint media release (at: http://foreignminister.gov.au/ releases/2012/bc_mr_120714.html).

45. The International Republican Institute 'Timor-Leste Holds Credible Parliamentary Elections, 8 July 2012 (at: www.iri.org/news-events-press-center/news/timor-leste-holds-credible-parliamen tary-elections).

46. No: 04/STAE/X/2011, Regulamento sobre os procedimentos de votação, contagem dos votos e apuramento dos resultados para as eleições presidenciais e parlamentares, aprovado pela Comissão Nacional de Eleições. Article 47, 8.

47. Ibid., Article 25.

48. Ibid., Article 48.

49. Ibid., Articles 48 and 16, respectively.

50. If consensus cannot be reached the complainer has the right to make a written appeal in a form available for that effect at each polling station, keeping a copy for him/herself.

51. Briefing by STAE staff to accredited international observers, 4 July 2012.

52. Nuno Canas Mendes, A multidimensionalidade da construção identitária em Timor-Leste, Lisboa: ISCSP, 2005, p.239.

53. Patrícia Jerónimo, 'Estado de Direito e Justiça Tradicional. Ensaios para um Equilíbrio em Timor-Leste.', in Rui Pinto Duarte, José Lebre de Freitas, Assunção Cristas, Marta Tavares de Almeida, and Vítor Pereira das Neves (eds), Estudos em Homenagem a Carlos Ferreira de Almeida, Vol. III, Coimbra: Almedina, 2010, pp.97-120.

54. Lei 3/2009 (see n.40 above), Article 6, 2.

55. Councils also include the Suco Leader, all village leaders and a nominated lian nain. Lei 3/2009 (see n.40 above), Article 5, 2.

56. Tsing (see n.2 above), p. 8 .

57. Ibid., p.10.

58. Ibid., p.8.

59. Ibid., p.18. 